\title{
Evaluation of the teaching practice course carried out with the Lesson Study Model
}

\author{
Şeyma Şahin and Abdurrahman Kılıç*
}

doi: http://dx.doi.org/10.18543/tjhe-8(1)-2020pp99-127

Received: 14 April 2020

Accepted: 22 October 2020

\begin{abstract}
The purpose of this research was to evaluate the teaching practice process carried out with the lesson study model. In this research "action research" approach was adopted. The study group of the research consisted of four Turkish Language and Literature pre-service teachers. Lesson study was carried out in nine weeks of the teaching practice course. Qualitative data collection techniques such as observation, unstructured focus group interview, and document review were used as data collection techniques. Pre-service teacher course observation forms obtained before the lesson study process, course plans, reflective diary forms, peer observation forms and student opinion forms obtained during the lesson study application process were analyzed with descriptive analysis method. At the end of the lesson study process, focus group interview data and letters written by pre-service teachers were analyzed by content analysis method. At the end of the research, it was seen that preservice teachers' perception of teaching profession changed in line with studentcentered understanding. It has been determined that pre-service teachers personally develop in terms of multi-faceted thinking, problem solving, self-confidence and patience and also improve professionally on issues such as coping with students, preparing plans, and producing activities.
\end{abstract}

Keywords: Lesson study; teaching practice; professional development; preservice teacher; action research.

* Şeyma Şahin (seyymasahin@gmail.com), PhD in Curriculum and Instruction, currently works as a teacher of Religious Culture and Moral Knowledge Course in a middle school affiliated with the Ministry of Education, Turkey.

* Abdurrahman Kılıç (abdurrahmankilic@duzce.edu.tr), PhD in Curriculum and Instruction, is Professor at the Educational Sciences department of the Faculty of Education, Duzce University, Turkey.

More information about the authors is available at the end of this article. 


\section{Introduction}

The most important aim of training pre-service teachers is to ensure their professional development and to have them ready for the profession. ${ }^{1}$ Teachers should be best trained in both subject matter knowledge and pedagogical competencies. The fact that teachers are equipped only with subject matter knowledge does not mean that education activities are carried out completely. ${ }^{2}$ The realization of the educational goals depends on the teachers' ability to convert their knowledge into a form that students can effectively gain. In addition to having good subject matter knowledge, teachers should both have skills to convey their knowledge effectively and knowledge necessary to manage the learning and teaching processes. ${ }^{3}$

Teaching practices of the pre-service teachers in schools are perceived as the most powerful component of preparation for the teaching profession. Preservice teachers' experiences gained at practice schools have a very important place in establishing the balance between theory and practice and gaining professional maturity. ${ }^{4,5}$ Teaching practice involves the intentional training of pre-service teachers to acquire the necessary knowledge, skills and values in both subject matter knowledge and pedagogical fields and it provides preservice teachers with opportunities to develop basic skills in the teaching profession. Pre-service teachers' performance in this process will strengthen them, help them merge theory to practice and provide a basis for their future success. ${ }^{6}$ In addition, teaching practice allows pre-service teacher to prepare

${ }^{1}$ Serap Akbaba Dağ, “A microteaching Lesson Study Practice to Improve Pre-Service Teachers' Knowledge of Teaching Fractions" (PhD diss., Dumlupınar University, 2014), 2.

${ }^{2}$ Emine Gözel, "Study of Progress of Class Teachers' Knowledge of Problem-Solving Based Math Teaching by Lesson Study" (PhD diss., Pamukkale University, 2016), 11.

${ }^{3}$ Gülşah Özdemir Baki, "Investigating the Development Process of Secondary Mathematics Teachers' Mathematical Pedagogical Content Knowledge: Lesson Study Model" (PhD diss., Atatürk University, 2017), 4.

${ }^{4}$ Mustafa Arslan and Mecit Sağlam, "Evaluation of Teaching Practice Course According to Opinions of Student Teachers," Hacettepe University Journal of Education 33, no. 1, (2018): 145 .

${ }^{5}$ Isabel Rots, Antonia Aelterman, Geert Devos, and Peter Vlerick, "Teacher Education and the Choice to Enter the Teaching Profession: A Prospective Study," Teaching and Teacher Education 26, (2010): 1628.

${ }^{6}$ Daudi Mika Mungure, “An Exploration of the Preparation and Organization of Teaching Practice Exercise to Prospective Science and Mathematics Teachers Toward Improving Teaching Profession at Morogoro Teachers' College," Journal of Education and Practice 7, no. 33, (2016): 212. 
for the real world of the teaching profession by giving them opportunity to apply teaching techniques. ${ }^{7}$

In Turkey, the teaching practices of the students who either study at the last year of faculties that train teachers, or participate in pedagogical formation are realized according to the provisions of the "Directive Regarding the Teaching Practice of the Pre-service Teachers in Educational Institutions Affiliated to the Ministry of National Education". In this context, the teaching practice course is carried out jointly by the provincial directorates for national education and faculties that train teachers. The teaching practice course aims to enable students to better prepare for the teaching profession. It also aims that the students should gain the ability to use their skills such as general knowledge, special field knowledge, teaching profession related skills, attitudes and behaviors that they obtained during their training, in an educational environment.

Researches show that the teaching practice process is not carried out effectively in Turkey. ${ }^{8}$ Pre-service teachers are not provided with the necessary environments. They make observations while they are supposed to teach. ${ }^{9}$ Moreover, they are not provided with sufficient feedback on the planning and implementation of the course ${ }^{10}$ Pre-service teachers behave reluctantly and can be unserious about the profession and the course, their motivation levels are low, they teach the course wrongly, and their profession and subject matter knowledge are not sufficient enough. ${ }^{11}$ Despite the theoretical courses and teaching practice course they took in undergraduate education, it is seen that pre-service teachers do not possess enough knowledge, skills and experiences. It is also seen that they do not have the

${ }^{7}$ Magdeline Mannathoko, "Does Teaching Practice Effectively Prepare Student-Teachers to Teach Creative and Performing Arts? The Case of Botswana," International Journal of Higher Education 2, no. 2 (2013): 115.

8 Yaşar Çelik and İbrahim Gül, "Evaluation of Teaching Practice Course According to Teacher Candidate's Opinions," Asian Journal of Instruction 6, no. 2 (2018): 82.

9 Necla Dönmez Usta and Ebru Turan Güntepe, "Opinion of the Pre-service Teachers on School Experience and Teaching Practice," Journal of International Social Research 9, no. 42 (2016): 1221.

10 Turan Paker, "Problems of Student Teachers Regarding the Feedback of University Supervisors and Mentors During Teaching Practice," Pamukkale University Faculty of Education Journal 1, no. 23 (2008): 138.

${ }^{11}$ Ethem Yeşilyurt and Çetin Semerci, "The Problems and Their Solutions of Practice Teachers in Teaching Practice Process," Akademik Bakış Dergisi, no. 27 (2011). 
necessary competencies such as planning, material preparation, time management, and effective communication with the students. ${ }^{12,13}$

One of the models developed to improve the subject matter knowledge and competencies of pre-service teachers and to fill the gap between theory and practice is "lesson study" model that has been put into practice with an increasing interest in the world. Lesson study has been used for the professional development of teachers in Japan for over a century and it is accepted and used as an effective method for professional development in other parts of the world. ${ }^{14}$ Lesson study includes regularly meeting teacher/pre-service teacher groups for subject selection and for design, implementation, testing and development of the courses. It also includes steps of careful planning, observations by peers, and reflecting and discussing observations with working group members by collaborating with one or more colleagues. ${ }^{15,16,17}$ The lesson study application allows teachers to become more knowledgeable about how their students learn, how they think and how the teaching and learning process affects student thinking. During the design phase of the course, teachers exchange ideas with students about communication. ${ }^{18}$

Lesson study has been shown to have important and permanent effects on improving teachers' knowledge and skills. ${ }^{19}$ Lesson study has been shown to contribute to the development of both new teachers and experienced teachers. ${ }^{20}$ The inclusion of lesson study in pre-service teacher education has been shown to help teachers develop a meaningful relationship with teaching profession at the beginning of their profession. ${ }^{21}$

${ }^{12}$ Hilal Kükey, "An Investigation of the Course Planning Process of Pre-Service Primary School Mathematics Teachers on Fifth Grade Fractions Topic Based on Lesson Study Model" (PhD diss., İnonu University, 2018), 3.

${ }^{13}$ Şükran Tok, "The Problems of Teacher Candidate's about Teaching Skills During Teaching Practice," Procedia Social and Behavioral Sciences no. 2 (2010): 4143.

${ }^{14}$ Raymond Bjuland and Reidar Mosvold, "Lesson Study in Teacher Education: Learning From a Challenging Case," Teaching and Teacher Education, no. 52 (2015): 84.

${ }^{15}$ Fer Coenders and Nellie Verhoef, "Lesson Study: Professional Development (PD) for Beginning and Experienced Teachers," Professional Development in Education 45, no. 2 (2018): 218.

${ }^{16}$ Fouada Hamzeh, "Lesson Study-Building Communities of Learning Among PreService Science Teachers" (Master diss., University of Windsor, 2014), 25.

17 Tracy C. Rock and Cathy Wilson, "Improving Teaching Through Lesson Study," Teacher Education Quarterly, no. 32 (2005): 78.

18 Tang Keow Ngang and Lim Chap Sam, "Principal Support in Lesson Study," ProcediaSocial and Behavioral Sciences, no. 205 (2005): 135.

${ }_{19}$ Rock, and Wilson, "Improving Teaching," 89.

${ }^{20}$ Coenders and Verhoef, "Lesson Study: Professional," 218.

${ }^{21}$ Hamzeh, "Lesson Study-Building," 1. 
The lesson study has also been shown to increase the capacity of teachers to develop positive emotions towards their professions, making the cooperative learning approach a part of their daily lives, strengthen teachers' thoughts about their own qualifications and increase their level of ownership feelings and their control of courses..$^{22}$ Moreover, it has also been shown that it contributes significantly to planning courses, student-centered teaching, focusing more on students and developing time management skills..$^{23}$

It was observed that most of the lesson study researches in Turkey were done in the field of Mathematics. ${ }^{24,25,26,27,28,29,30,31,32,33,34,35}$ Apart from these,

${ }^{22}$ Ayşegül Serbest, "The Examination of Lesson Study’s Impacts with Meta-Synthesis" (Master diss., Karadeniz Tecnical University, 2014), 115.

${ }^{23}$ İlknur Bayram and Fatma B1kmaz, "Exploring the Lesson Study Experience of EFL Instructors at Higher Education: A Pilot Study," Journal of Qualitative Research in Education 6, no. 3 (2018): 327.

${ }^{24}$ Durdu Nur Aktürk, "Examination of the Mathematics Teachers' Views on the STEM Activities Developed within the Scope of Lesson Study" (Master diss., Eskisehir Osmangazi University, 2019).

${ }^{25}$ Ruhşen Aldemir, "Investigation Development of Prospective Mathematic Teachers' Technological Pedagogical Content Knowledge by Micro Teaching Lesson Study: The Case of Solid Objects" (Master diss., Atatürk University, 2017).

${ }^{26}$ Müjgan Baki and Selahattin Arslan, "Examining the Effect of Lesson Study on Prospective Primary Teachers' Knowledge of Lesson Planning," Turkish Journal of Computer and Mathematics Education 6, no. 2 (2015).

${ }^{27}$ Gamze Kurt Birel, "A New Approach in the Context of Mathematics Education Research: Lesson Study," Studies in Educational Research and Development 1, no. 1 (2017).

${ }^{28}$ Elif Boran and Kamuran Tarım, "The Opinions of Secondary School Mathematics

Teachers about the Lesson Study," Turkish Journal of Computer and Mathematics Education 7, no. 1 (2016).

${ }^{29}$ İbrahim Budak, Ayfer Budak, Işıl Bozkurt, and Bülent Kaygın, "Lesson Study Implementation with Pre-Service Mathematics Teachers," e-Journal of New World Sciences Academy 6, no. 2 (2011).

${ }^{30}$ Pınar Güner and Didem Akyüz, "Lesson Study Professional Development Model: Investigating Noticing Skills of Prospective Mathematics Teachers," Elementary Education Online 16, no. 2 (2017).

31 Ümit Kaya, "Evaluation of Lesson Study Model Based Professional Development Applications of High School Mathematics Teachers" (Master diss., Cumhuriyet University, 2018).

${ }^{32}$ Hilal Kükey, "An Investigation of the Course Planning Process of Pre-Service Primary School Mathematics Teachers on Fifth Grade Fractions Topic Based on Lesson Study Model" (PhD diss., İnonu University, 2018).

33 Özdemir Baki, "Investigating the Development."

${ }^{34}$ Deniz Özen, "Development of Geometric Thinking of Elementary School Mathematics Teachers: A Lesson Study" (PhD diss., Anadolu University, 2015).

${ }^{35}$ Ramazan Yurdakul, "Designing and Evaluation of a Web Site to Facilitate the Implementation Lesson Study Model in In-Service Trainings of Mathematics Teachers" (Master diss., Cumhuriyet University, 2019). 
some other studies in the fields of primary school teaching, ${ }^{36,37,38}$ Social Studies $^{39}$ and English ${ }^{40}$ were also found. However, no studies in the field of Turkish Language and Literature, which is the common area of pre-service teachers in this study, have been encountered. In this respect, it is thought that this study conducted with pre-service teachers of Turkish Language and Literature will contribute to the field.

"Formation Certificate Program" is a program designed for students who graduated from faculties other than education faculties to obtain a teaching certificate. Formation education is offered by the universities to students who graduated from particular departments of the universities determined by the Higher Education Institution. "Teaching practice" is one of the courses in this program. The teaching Practice course is a weekly course of 8 hours, 2 of which are theoretical and 6 of which are practice. The theoretical part of the course is held at the university, and the practical part is held in a school affiliated to the Ministry of National Education during working hours. It is aimed that teacher candidates will gain teaching skills in the classroom personally. Since the teaching practice course is purely practice-oriented, it is a very suitable course for the application of the lesson study model. When the framework of the teaching practice course is designed in accordance with this model, it is thought that the teaching process will become more functional in terms of pedagogy and professionalization. ${ }^{41}$ In this sense, the purpose of this research is to evaluate the effects of the teaching practice process carried out with the lesson study research model on Turkish Language and Literature pre-service teachers. For this purpose, the following research questions were addressed.

- What are the opinions of the pre-service teachers regarding the teaching practice process carried out with the lesson study model?

- What are the opinions about the pre lesson study process?

- What are the opinions about the lesson study process?

- What are the opinions about the post lesson study process?

36 Dağ, "A microteaching."

${ }^{37}$ Gözel, "Study of Progress."

${ }^{38}$ Esin Meral Kandemir, "An Application to Improve Teaching Skills of Classroom Teachers: Lesson Study” (PhD diss., Pamukkale University, 2018).

39 Tolgahan Ayantaş, "Lesson Study Practice in The Development of Professional Teaching Knowledge of Pre-Service Teachers of Social Studies" (Master diss., Ankara University, 2019).

${ }^{40}$ Bayram and B1kmaz, "Exploring the Lesson Study."

${ }^{41}$ Rafet Günay, Banu Yücel Toy, and Elif Bahadır, "Lesson Study Model in Teacher Education and a Proposal toward Pre-service Teaching Practices in Turkey," Journal of International Social Research 9, no. 42 (2016): 1226. 


\section{Method}

The research was carried out with the "action research" method which is one of the qualitative research designs. Action research is an applied, cyclical and problem-solving oriented approach. Action research has started to be accepted as a part of professional development, because as it is thought that it can provide new understanding about school-based problems and improve education. ${ }^{42}$ Action research is thought to be an effective way to ensure professional development of educators and to improve educational practices. ${ }^{43}$

The action research was gathered in three groups as "scientific-technical action research", "practical-deliberative action research" and "critical emancipatory action research". ${ }^{44}$ In this research, "practical-deliberative action research" approach was adopted. With this type of action research, researchers together with practitioners identify the problem, underlying causes of the problem, and possible interventions to solve the problem. Within the scope of this research, the researchers together with the preservice teachers tried to solve the problems of the teaching practice using action research.

\section{II.1. Study group}

In qualitative research, the aim is to obtain maximum information from the participants who are thought to give the most comprehensive information about the research problem through purposeful sampling method.$^{45}$ The study group of the research, selected using the purposeful sampling method, consisted of four senior students enrolled in a Department of Turkish Language and Literature at a state university. These students also continued the 2019-2020 fall term "teaching certificate program" offered by the same state university and took the "teaching practice" course. All of the selected

${ }^{42}$ Taylor, Claire, Min Wilkie, and Judith Baser, Doing Action Research: A Guide for School Support Staff(London: Paul Chapman Publishing, 2006), 2.

${ }^{43}$ Margaret Vaughna, Seth A. Parsons, Susan Kologi, and Melissa Saul, "Action Research as a Reflective Tool: A Multiple Case Study of Eight Rural Educators' Understandings of Instructional Practice," Reflective Practice 15, no. 5 (2014): 634.

${ }^{44}$ James McKernan, Curriculum Action Research. A Handbook of Methods and Resources for the Reflective Practitioner (London: Kogan Page, 1991), 15.

${ }^{45}$ Svend Brinkmann, Qualitative Interviewing: Understanding Qualitative Research (New York: Oxford University Press, 2013), 57. 
pre-service teachers were females. These pre-service teachers were coded as $\mathrm{T} 1, \mathrm{~T} 2, \mathrm{~T} 3$, and $\mathrm{T} 4$.

\section{II.2. Data collection}

Before data collection, permission was obtained from the Scientific Research and Publication Ethics Committee of Duzce University with the decision numbered 2020/109 and 2020/110 and dated 04/06/2020.

The study used observation, unstructured focus group interview and document review techniques as data collection techniques. The study used "pre-service teacher course observation forms", "course plans", "reflective diary forms", "peer observation forms", "student opinion forms", "preservice teachers" letters" and "focus group interview forms" as data collection tools. The use of each one of these tools is described below:

- The pre-service teacher course observation forms (22 forms in total) were filled by each pre-service teacher during the first three weeks.

- Together, the researchers and pre-service teachers prepared one course plan every week (a total of 9 major course plans), and pre-service teachers prepared two revised plans (a total of 18 revised plans) each week.

- At the end of each course, the pre-service teacher who is responsible for the teaching of the course filled the reflective diary forms ( 27 forms in total), and the other three pre-service teachers filled the peer observation forms (27 forms in total) during teaching of the course.

- In the last five minutes of each course, volunteer students completed the student feedback form (124 forms in total), in which they wrote their views on the teaching of the course.

- Each pre-service teacher wrote a letter (4 letters in total) at the end of the semester, in which they shared their feelings and thoughts about the process.

- A focus group interview lasting about 59 minutes was held with the four pre-service teachers at the end of the semester.

\section{II.3. Data analysis}

Before the lesson study process, the data obtained by the pre-service teacher course observation forms and during the applications of the lesson 
study process the data obtained by course plans, reflective diary forms, peer observation forms and student opinion forms were analyzed using descriptive analysis method. In descriptive analysis, the data obtained are summarized and interpreted according to the previously determined categories. ${ }^{46}$ The categories were determined in line with the literature review and purpose of this research while creating data collection tools. The data collected within the scope of the research were carefully read and placed in the determined categories.

At the end of the lesson study process, the focus group interview data and the letters written by pre-service teachers were analyzed using content analysis method. Content analysis can be defined as a detailed and careful examination of a particular material to define patterns, categories or meanings. Content analysis process was carried out in three stages as coding, classification and association.$^{47}$ First of all, the data collected in the form of voice recording were converted to text. The data collected from different sources were combined and grouped and made ready for analysis. The forms are coded to express each participant. These codes, which are used instead of the names of the participants, are also used in direct quotations. In this research, "databased coding" type was adopted in the coding of the data and the codes were improved during the analysis process. In this phase, the encoded data were examined more closely and the category formation process was carried out based on the characteristics of the data. Then, the processes of distributing data into categories, combining data into upper categories, and creating subcategories were carried out. Later, the relationships and differences between the formed categories were examined. At this stage, the data that was divided into pieces by coding were brought together analytically in an orderly manner and a new conceptual framework was formed.

\section{II.4. Validity and reliability}

In order to ensure the validity and reliability of the research, the following processes were carried out:

- Data diversification was made.

- Expert opinion was taken during the development of data collection tools.

46 Abdurrahman Kılıç, Mustafa Aydın, Burcu Ökmen, and Şeyma Şahin, Kuramdan Uygulamaya İhtiyaç Belirleme (Ankara: Pegem Yayıncılık, 2019), 361.

${ }^{47}$ Kılıç, Aydın, Ökmen, and Şahin, Kuramdan Uygulamaya, 362. 
- In the content analysis, the creation of categories was done meticulously.

- The data upon which content analysis were done were coded twice by the researcher with an interval of four weeks. Miles and Huberman's (1994) formula of conformity was used in consistency calculations and it was observed that there was an $82.72 \%$ conformity.

- Objectivity has been provided through direct quotations from data collection forms.

\section{II.5. Application process}

The application process was conducted by the faculty member responsible for the teaching practice course at the university together with his doctoral student. Literature emphasizes that inexperienced teachers and pre-service teachers require guidance of a specialist to conduct lesson study as they do not have enough experience..$^{48}$

Teaching practice course consisted of 2 hours of a theoretical part and 6 hours of practical part at high school per week. The theoretical and practical part progressed in parallel. The theoretical parts of the teaching practice course, which lasted 14 weeks in total, were held at the university, one hour every week on Thursdays. Pre-service teachers were assigned to an Anatolian High School for application of the teaching practice course. They attended three 12th grade classes (12A, 12B, and 12E), two hours a week for a total of six hours, on Monday, Tuesday and Thursday.

Before the application started, a term plan was elaborated for the teaching practice course. In the first week, pre-service teachers, responsible faculty member and the researchers met in the theoretical course at the university, and pre-service teachers were given information about the process. In the theoretical course at the university, the curriculum of the course, sample course plans and annual plans were examined together by pre-service teachers and the researchers in the second week.

The pre-service teachers met with the guiding teachers and students at the school where they practiced teaching in the first week. In the 1st, 2nd and 3 rd weeks, pre-service teachers did not teach when they went to practice schools, and filled the observation forms by observing the guiding teacher in three different 12th grade classes, in six different courses, and for a total of 12-hours, for three weeks.

${ }^{48}$ Serbest, “The Examination,” 109. 
In the third week, in the theoretical course at the university, the preservice teacher course observation forms filled in the first three weeks were analyzed, the problems experienced during the application process were identified, and the first action plan was prepared in line with the findings. Starting from the 4th week, in theoretical courses at the university, course plans for the following weeks continued to be prepared. Pre-service teachers prepared the plan of the final week by themselves.

Starting from the fourth week, pre-service teachers carried out their practices in their schools under the supervision of the guiding teacher, and also for one week under the guidance of the researchers. In the application phase of the course, while a pre-service teacher, who teaches the course, was responsible for both filling the "self-assessment form" and having the volunteer students fill the "student opinion form", other three pre-service teachers were responsible for filling the "peer assessment form".

Lesson study application was carried out in nine weeks of the teaching practice course actively. Each lesson study cycle lasted one week. The course plans of pre-service teachers in the lesson study process are given in Table 1:

As shown in Table 1, pre-service teachers were assigned the courses of three classes (12-A, 12-B, 12-E) of the 12th grades during the semester. Four pre-service teachers attended each class together. The application consisted of nine cycles. In each cycle, three pre-service teachers did the teaching and

Table 1

Lesson Study Term Plan

\begin{tabular}{|l|l|c|c|c|}
\hline \multirow{2}{*}{\multicolumn{2}{|c|}{ Cycles }} & \multicolumn{3}{c|}{ Application Classes } \\
\cline { 3 - 5 } & 12-A & 12-B & 12-E \\
\hline 1. Cycle & 04-08 November & ÖA1 & ÖA2 & ÖA3 \\
\hline 2. Cycle & 11-15 November & ÖA4 & ÖA1 & ÖA2 \\
\hline 3. Cycle & 25-29 November & ÖA3 & ÖA4 & ÖA1 \\
\hline 4. Cycle & 02-06 December & ÖA2 & ÖA3 & ÖA4 \\
\hline 5. Cycle & 09-13 December & ÖA1 & ÖA2 & ÖA3 \\
\hline 6. Cycle & 16-20 December & ÖA4 & ÖA1 & ÖA2 \\
\hline 7. Cycle & 23-27 December & ÖA3 & ÖA4 & ÖA1 \\
\hline 8. Cycle & 30 December-03 January & ÖA2 & ÖA3 & ÖA4 \\
\hline 9. Cycle & 06-10 January & ÖA1 & ÖA2 & ÖA3 \\
\hline
\end{tabular}




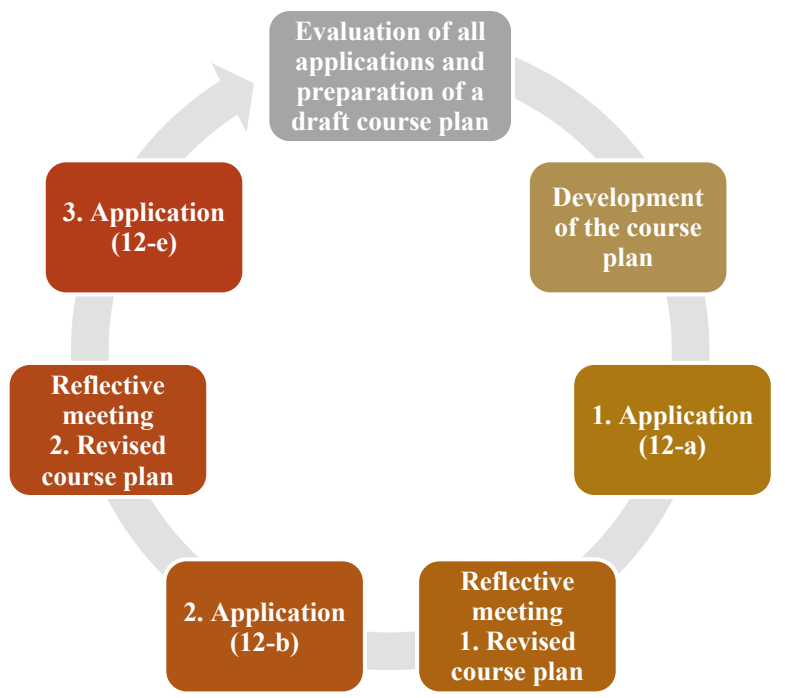

Figure 1

Lesson Study Weekly Cycle

the fourth one did only observations in that cycle. In one class, while a preservice teacher was teaching a lesson, the other three pre-service teachers did observations. Three pre-service teachers had the opportunity to teach seven times while, one pre-service teacher taught six times.

The lesson study weekly cycle consists of seven stages. There is a course plan and two revised plans in each cycle. These stages are shown in Figure 1:

As shown in Figure 1, each lesson study cycle started with the preparation of the next week's course plan (same plan for all three classes). Every Thursday, pre-service teachers and researchers met for the theoretical course and prepared the next week's course plan in general. Course plans were prepared by considering the annual plans developed by the guiding teacher in line with the Turkish Language and Literature curriculum. Course plans were planned in accordance with the student-centered understanding, and every week different methods and techniques in which students could be active were included. The course plan, whose preliminary preparations were done together, was completed by pre-service teachers and sent to researchers via WhatsApp on weekend, and the plan was finalized through mutual messages. 
The prepared plan was applied by the selected pre-service teacher. After the application, the four pre-service teachers held the first reflective meeting and evaluated the course process. They prepared the first revised course plan by making some decisions as a result of the evaluations. Then, the plan was applied for the second time. The second reflective meeting was held after the application, and some decisions were made and the second revised plan was prepared. After that, the plan was applied for the third time. Sometimes, researchers also attended the revision meetings, and some other times preservice teachers exchanged ideas with the researchers about application of the plan and the changes made in the revised plan via WhatsApp messages or phone calls. The guiding teacher also attended the reflective meetings in some weeks.

The evaluation of the third application of the plan along with the other two applications of it was done by pre-service teachers and researchers during the theoretical course on Thursdays. At this stage, reflective diaries of pre-service teachers, peer evaluation forms and student opinion forms were examined, and decisions were made regarding the next plan according to the results achieved. In line with these decisions, the next week's course plan was prepared and the cycle of the week was completed.

\section{Results and discussion}

Findings are introduced under three titles as "opinions about the pre lesson study process", "opinions about the lesson study process" and "opinions about the post lesson study process".

\section{III.1. Opinions about the pre-lesson study process}

Pre-service teachers' opinions related to the pre-process are given in Table 2: 
Table 2

Opinions About the Pre Lesson Study Process

\begin{tabular}{|c|c|}
\hline Categories & Codes \\
\hline $\begin{array}{l}\text { Attitude towards } \\
\text { Teacher }\end{array}$ & $\begin{array}{l}\text { She wanted to be a teacher } \\
\text { She regarded teaching as a comfortable occupation }\end{array}$ \\
\hline $\begin{array}{l}\text { Pedagogical } \\
\text { Information }\end{array}$ & $\begin{array}{l}\text { She did not know how to make a course plan } \\
\text { She did not know that it was necessary to make a plan } \\
\text { before going to class } \\
\text { She advocated plain lecturing } \\
\text { She was against the activity, and had doubts } \\
\text { She did not believe in the benefit of the plan } \\
\text { She does not have any knowledge about method, } \\
\text { technique and activity }\end{array}$ \\
\hline Self-Sufficiency & $\begin{array}{l}\text { She had no self-confidence and was suspicious about } \\
\text { herself } \\
\text { She considered herself inadequate in all respects } \\
\text { She was inexperienced } \\
\text { She was uneasy, stressed, nervous, excited } \\
\text { She thought she couldn't do it; she would have a hard time }\end{array}$ \\
\hline Internship Group & $\begin{array}{l}\text { She was thinking that her advisor was tough person } \\
\text { She was very upset, anxious and sleepless when she } \\
\text { heard the name of the advisor } \\
\text { She was comparing herself with other internship groups } \\
\text { She was very upset when the internship school was } \\
\text { changed }\end{array}$ \\
\hline Tasks & $\begin{array}{l}\text { Making a course plan felt like chore } \\
\text { She thought the forms they would fill were unnecessary } \\
\text { She was afraid of preparing files } \\
\text { She knew that everything was for her own good. This } \\
\text { made her relaxed } \\
\text { She thought there were strict rules } \\
\text { Their actions (activities, materials, observations) were } \\
\text { very intimidating } \\
\text { She thought that what she would do would not be liked } \\
\text { by the others } \\
\text { She thought it was too much to teach seven times in a } \\
\text { semester }\end{array}$ \\
\hline
\end{tabular}

As shown in Table 2, Pre-service teachers' opinions about pre lesson study were gathered under five categories. These categories are "Attitude towards Teacher", "Pedagogical Information", "Self-Sufficiency", "Internship Group" and "Tasks". 
It is seen that pre-service teachers want to be teachers and they think that being a teacher is an easy profession. However, they are pedagogically insufficient and their beliefs in self-efficacy are low. It is also seen that, initially, pre-service teachers are not satisfied with the internship groups, are afraid of the tasks they will perform, and they believe that the work and procedures they will do are unnecessary.

Some quotations from the opinions of the pre-service teachers (T) under these categories are given below:

T1: As far as I can hear from my environment, it was mentioned that the teaching profession is always a comfortable profession. Weekends, onemonth breaks and three-months breaks...

T2: "When I started the internship process, I was faced with a surprise change and I saw that my school and guidance counselor had changed. I was very upset about this. I met you at our first meeting, what we will do was intimidating to me.

T3: I am uneasy, since the time my guiding teacher has given us information about what to do. I was very intimidated that we had to prepare observation forms, student opinion forms, reflective diaries, activities according to our methods and techniques, and more importantly, preparing course plans.

T4: I did not know that I had to prepare a plan when I was going to a class. I realized how inexperienced and uninformed I am about my dream job.

The difficulties that pre-service teachers experience may be related to not being an education faculty graduate. In a research it was found that Turkish teaching pre-service teachers give more importance to practicing pedagogy education they receive in the classroom than Turkish Language and Literature pre-service teacher. Turkish Language and Literature pre-service teachers think that subject matter knowledge is the most important determinant in teacher self-efficacy. ${ }^{49} \mathrm{In}$ another research, it was found that the self-efficacy perceptions of education faculty students were higher than science and literature faculty students' perceptions.$^{50}$ These three studies support the results of this research. On the other hand, in an other research it was determined that there was no statistically significant difference in self-

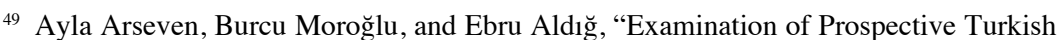
Language Teachers and Turkish Language and Literature Teachers' Self-Efficacy Beliefs," IJOESS 6, no. 21 (2015): 61.

${ }^{50}$ Gökhan Arastaman, "Examination of Education and Arts and Sciences Faculty Students' Self-Efficacy Beliefs and Their Attitudes Toward Teaching Profession," KEFAD 14, no. 2 (2013): 211. 
efficacy beliefs towards the profession of both the Faculty of Education students, and the Faculty of Science and Literature students who also take pedagogical formation training. ${ }^{51}$ This result does not seem compatible with this research.

\section{III.2. Opinions about the lesson study process}

Pre-service teachers' opinions about the lesson study process were examined under two subtitles as; "Opinions Related to the Process" and "Opinions about the Relationships".

III.2.1. Opinions related to the process

Pre-service teachers' opinions related to the process are given in Table 3:

\section{Table 3}

Opinions About the Lesson Study Process

\begin{tabular}{|l|l|}
\hline \multicolumn{1}{|c|}{ Categories } & \multicolumn{1}{c|}{ Codes } \\
\hline $\begin{array}{l}\text { Preparing Course } \\
\text { Plan }\end{array}$ & $\begin{array}{l}\text { She was very angry when her course plan was not liked } \\
\text { She was getting angry with her friends while she was } \\
\text { preparing the course plan } \\
\text { Getting ready for the course was a burden and difficult } \\
\text { She has improved herself in preparing activities over } \\
\text { time } \\
\text { She was very angry while she was preparing the first few } \\
\text { course plans } \\
\text { It was difficult to produce material } \\
\text { In the beginning, she had hard times, was exhausted and } \\
\text { was sleepless while preparing course plans } \\
\text { It was difficult to find motivation, draw attention, and } \\
\text { transition to the course in the plan } \\
\text { As time moves (after preparing 3-4 plans) preparing } \\
\text { course plans became easier }\end{array}$ \\
\hline
\end{tabular}

${ }^{51}$ Metin Elkatmış, Murat Demirbaş, and Nurcan Ertuğrul, "Self-Efficacy Beliefs of Students Who Take the Pedagogic Training Program in the Faculty of Arts and Sciences and Students in the Education Faculty Towards Teaching Profession," Pegem Journal of Education and Instruction 3, no. 3 (2013): 47. 


\begin{tabular}{|l|l|}
\hline \multicolumn{1}{|c|}{ Categories } & \multicolumn{1}{|c|}{ Codes } \\
\hline Preparing Revised & $\begin{array}{l}\text { Revised plans enabled the improvement of the course } \\
\text { Revised plans provided an opportunity to correct errors } \\
\text { Revised plans helped class management } \\
\text { In the revised plans, beautiful things done in the other } \\
\text { courses were used as examples } \\
\text { Revised plans gave an idea about how to approach } \\
\text { students } \\
\text { Revised plans contributed to group formation } \\
\text { Revised plans helped to adjust activity times } \\
\text { Revised plans were reorganized according to the } \\
\text { reactions from student }\end{array}$ \\
\hline Application of the \\
Plan & $\begin{array}{l}\text { The plan provided confidence and relieved the course } \\
\text { The plan provided context through the course } \\
\text { Time management was done easily with the plan } \\
\text { She knew what to do through the course with the help } \\
\text { of the plan } \\
\text { At first, she looked at the course plan frequently, and } \\
\text { then she internalized the plan }\end{array}$ \\
\hline Activities & $\begin{array}{l}\text { Students who never participated the course were } \\
\text { participated } \\
\text { The course was given with student-centered activities } \\
\text { The activities enlivened the class environment, draw } \\
\text { attention of the students, and satisfied them } \\
\text { Activities enabled students to learn } \\
\text { Even though there were some minor problems in the } \\
\text { activities, they were completed with no problem } \\
\text { All students were reached with the activities } \\
\text { In the activities, whole of the 40-minute course time was } \\
\text { used efficiently } \\
\text { The students were in interaction with each other in the } \\
\text { activities } \\
\text { The students attended the activities of the course with } \\
\text { pleasure and had a lot of fun } \\
\text { All of the students worked with the group }\end{array}$ \\
\hline & \\
\hline &
\end{tabular}

As shown in Table 3, pre-service teachers' opinions about teaching of the course were gathered under four categories. These categories are "Preparing Course Plan", "Preparing Revised Course Plan", "Application of the Plan", and "Activities".

It is seen that initially, pre-service teachers had difficulties in preparing course plans, producing activities and materials, but they gained experience in time and did their job easily. It was also observed that the pre-service 
teachers provided benefits in development of the courses in terms of adjusting timing of the revised plans, formation of the groups and controlling of the class.

Some quotations from the opinions of the pre-service teachers on this subject are given below:

T1: Preparing a plan was the thing that tired me the most during this process. I was both inexperienced and I had no self confidence in this matter."

T2: We tried to prepare course plans staying sleepless all night long and by getting angry with you. You said that as time goes on this job would be very simple for us, so it really happened.

T3: As a result of hard work, we taught students a lot of things through activities. Teaching something to students made me feel happy.

T4: When I saw that the students attended my class without getting bored and with joy, my self-confidence increased and I felt happy. They all interested in what I did.

This situation shows that the lesson study process has very positive effects on the preparation for the course. Similarly, in a research it was determined that pre-service teachers showed progress in designing the course and conducting student learning during the lesson study process.$^{52}$ It was also revealed in an other study that the model contributes to teachers in course planning. ${ }^{53}$ Similarly, in an other study it was indicated that the lesson study method is very useful in the professional development of teachers. ${ }^{54}$ In a meta-synthesis study on the influence areas of the lesson study method, it was determined that, with the lesson study, the development and change in the instructional practices and guidelines in the classroom were positive. ${ }^{55} \mathrm{In}$ an other research it was found that the lesson study method provided preservice teachers with the opportunity to practice and that these studies contributed greatly to them professionally. ${ }^{56}$ In the same way, it was revealed

${ }^{52}$ Meiliasari Meiliasari, "Lesson Study with Pre-Service Teachers: Investigating the Learning of Pre-Service Teachers in Lesson Study Model of Teaching Practice Course" (Fifth International Conference on Science and Mathematics Education CoSMEd, Malaysia, 2013), 9-10.

${ }_{53}$ Bayram and B1kmaz, "Exploring the Lesson Study," 325.

${ }^{54}$ Rock, and Wilson, "Improving Teaching," 89.

55 Serbest, "The Examination," 105.

${ }^{56}$ George Zhou and Judy Xu, "Microteaching Lesson Study: An Approach to Prepare Teacher Candidates to Teach Science Through Inquiry," International Journal of Education in Mathematics, Science and Technology 5, no. 3 (2017): 243. 
that the application of the lesson study provides significant advances in the teaching skills of pre-service teachers.$^{57} \mathrm{In}$ a research work, it was concluded that the activities carried out with the lesson study method are fun and interesting for the students. ${ }^{58}$ Similarly, in an other research work it was concluded that the in-class activities carried out with lesson study contributed to students' reaching a more positive perspective towards the course or activities. ${ }^{59}$ In the same way, in a study it was revealed that student-centered methods have a positive effect on students' attitudes towards the course compared to traditional methods.$^{60}$ In an other study, it was found that collaborative student-centered learning activities have more positive effects on students' attitudes towards courses than traditional learning and teaching methods. ${ }^{61}$

III.2.2. Opinions about the relationships

The pre-service teachers' opinions about the relationships are given in Table 4:

${ }^{57}$ K. Merdekawati, "The Implementation of Lesson Study to Improve the Teaching Skills of Chemistry Teacher Candidates" (International Conference on Science and Technology, Indonesia, 2018), 6.

58 Abdullah Coşkun, "The Application of Lesson Study in Teaching English as a Foreign Language," Inonu University Journal of the Faculty of Education 18, no. 1, (2017): 151-162.

59 Selda Şan and Zafer İbrahimoğlu, "The Impact of Using Student-Centered Activities on Students' Academic Achievement in Social Studies Course and Student's Views," Abant Izzet Baysal University Faculty of Education Journal 17, no. 4 (2017): 2153.

${ }^{60}$ Beyda Topan, "Effects of Student-Centered Methods on Academic Achievement and Attitude towards the Subject: A Meta Analysis Study" (Master diss., Kocaeli University, 2013), 115.

${ }^{61}$ Gökhan Baş, “The Effects of Cooperative Learning Method on Students' Achievement, Their Attitude Towards the Lesson and the Maintenance Levels of Their Achieved Knowledge in English Lessons," National Education, no. 184 (2009): 252. 


\section{Table 4}

Opinions About the Relationships

\begin{tabular}{|c|c|}
\hline Categories & Codes \\
\hline $\begin{array}{l}\text { Relationship with } \\
\text { the Students }\end{array}$ & $\begin{array}{l}\text { She became friends with the students } \\
\text { She liked to chat with the students } \\
\text { Student opinions improved her } \\
\text { Her relationship and bond with students became } \\
\text { stronger, and her communication strengthened } \\
\text { She saw that the students' attitude was not toward her } \\
\text { She was able to understand their interests } \\
\text { The students showed their reactions }\end{array}$ \\
\hline $\begin{array}{l}\text { Relationship with } \\
\text { the peers }\end{array}$ & $\begin{array}{l}\text { She improved herself with peer reviews } \\
\text { It was upsetting to make little contribution to her group } \\
\text { friends } \\
\text { She observed the good aspects of her friends and } \\
\text { improved herself } \\
\text { Planning in a group made a lot of contributions, she } \\
\text { couldn't have done it alone }\end{array}$ \\
\hline $\begin{array}{l}\text { Relationship } \\
\text { with the Guiding } \\
\text { Teacher }\end{array}$ & $\begin{array}{l}\text { They contributed to the guiding teacher on course plans } \\
\text { and activities } \\
\text { The guiding teacher sometimes contributed to them in } \\
\text { revisions } \\
\text { The guiding teacher was satisfied with what was done } \\
\text { over time, her bias was changed }\end{array}$ \\
\hline $\begin{array}{l}\text { Relationship with } \\
\text { the other Teachers }\end{array}$ & $\begin{array}{l}\text { They became famous among the other teachers as game } \\
\text { playing teachers } \\
\text { The teachers wondered about them } \\
\text { They imitated the patience and smiling face of the } \\
\text { teachers }\end{array}$ \\
\hline $\begin{array}{l}\text { Relationship with } \\
\text { himself/herself }\end{array}$ & $\begin{array}{l}\text { She physically got tired } \\
\text { She gained more experience and improved herself after } \\
\text { each passing week } \\
\text { At first, she was afraid, excited, felt helpless } \\
\text { She felt valuable } \\
\text { She was happy to be able to express herself } \\
\text { The process was a thorny road and thorns sank in her } \\
\text { feet } \\
\text { Her self-confidence increased, she relaxed and her } \\
\text { anxiety was gone }\end{array}$ \\
\hline
\end{tabular}


As shown in Table 4, pre-service teachers' opinions about relations with individuals were gathered under five categories. These categories are "Relationship with the Students", "Relationship with the peers", "Relationship with the Guiding Teacher", "Relationship with the other Teachers" and "Relationship with himself/herself".

It is seen that pre-service teachers establish good relations and improved themselves with opinions of the students. Working with peers has contributed to pre-service teachers to improve themselves and to make the process easier. It is also seen that the application teacher contributed to the pre-service teachers as well as the pre-service teacher contributed to the applications teacher in terms of course plan, activity and material. It was observed that initially pre-service teachers experienced feelings such as fear and excitement in the process, but over time they gained experience had more trust in themselves, and their anxiety level was decreased.

Some quotations from the opinions of the pre-service teachers on this subject are given below:

T1: They were my students and also became my friends. They came to us every Thursday at lunchtime and talked to us. We were talking to them about the activities and future plans.

T2: I learned a lot from my friends. I saw my own shortcomings while watching them.

T3: The application teacher also contributed to the evaluations of the revisions. He also contributed to organization of the activities. Sometimes he was with us.

T4: I couldn't write the plan alone. When my friends said let's do this in this way, we were seeing different aspects. It was very convenient to be together during the plan preparation phase.

Thus, the study established that working with peers has positive effects during the lesson study process. This is in agreement with other studies. In a study it was emphasized that peer collaboration is very valuable for teachers' professional development. ${ }^{62}$ In an other study it was determined within the scope of lesson study that planning done by pre-service teachers as a group is more effective than planning done by individual pre-service teachers. ${ }^{63}$ In a study it was stated that lesson study encourages collaboration and tolerance

${ }^{62}$ Rock and Wilson, "Improving Teaching," 84.

${ }^{63}$ Hilal Kükey, "An Investigation of the Course Planning Process of Pre-Service Primary School Mathematics Teachers on Fifth Grade Fractions Topic Based on Lesson Study Model" (PhD diss., İnonu University, 2018), 93. 
in generating ideas and enables pre-service teachers to work more closely with each other. ${ }^{64}$

\section{I.1. Opinions about the post lesson study process}

Pre-service teachers' opinions related to the post-process are given in Table 5:

\section{Table 5}

Opinions About the Post Lesson Study Process

\begin{tabular}{|l|l|}
\hline \multicolumn{1}{|c|}{ Categories } & \multicolumn{1}{c|}{ Codes } \\
Berception of & $\begin{array}{l}\text { He understood how correct profession he chose } \\
\text { He prejudices against student-centered education were } \\
\text { demolished } \\
\text { He understood that being a teacher in not only teaching } \\
\text { courses } \\
\text { He understood that being a teacher is not an easy } \\
\text { occupation } \\
\text { He understood that being a teacher means taking some } \\
\text { responsibilities } \\
\text { He has changed his perception of being a teacher in his } \\
\text { mind } \\
\text { She liked being teacher and wants to be a teacher }\end{array}$ \\
\hline Individual \\
Development & $\begin{array}{l}\text { She started to be able to think with multiple aspects } \\
\text { She learned how to be patient even though She is an } \\
\text { impatient person } \\
\text { She does not care about what people think about him } \\
\text { She improved his self-confidence } \\
\text { She can express himself very well } \\
\text { She realized his potentials, proud of himself } \\
\text { She learned how to overcome his fears } \\
\text { She is not afraid of solving problems and he became } \\
\text { solution } \\
\text { She was mentally improved himself }\end{array}$ \\
\hline
\end{tabular}

${ }^{64}$ Zanaton Hj Iksan, Siti Nor Aishah Mohd Nor, Siti Nordiyana Mahmud, and Effandi Zakaria, "Applying the Principle of 'Lesson Study' in Teaching Science," Asian Social Science 10, no. 4 (2014): 108-113. 


\begin{tabular}{|c|c|}
\hline Categories & Codes \\
\hline $\begin{array}{l}\text { Occupational } \\
\text { Development }\end{array}$ & $\begin{array}{l}\text { She understood the necessity of the forms } \\
\text { She was thinking that he can be good teacher } \\
\text { Occupationally improved himself and gained experiences } \\
\text { She learned how to manage students } \\
\text { She got used to be a teacher and overcame his } \\
\text { excitement } \\
\text { She learned how to prepare plans and produce and } \\
\text { activities } \\
\text { She believed the benefit of the pan } \\
\text { She learned by applying all steps } \\
\text { In seven course times, he learned things that he can } \\
\text { learn in seven years } \\
\text { She things that teaching seven times is great experience }\end{array}$ \\
\hline Internship Process & $\begin{array}{l}\text { She wanted to continue one more semester } \\
\text { It was a good an experience, he had some difficulties but } \\
\text { it worth it } \\
\text { She could have taught even more courses } \\
\text { She feels lucky about being a part of this group } \\
\text { She felt good about seeing himself on the field } \\
\text { She thinks that he will benefit from his internship } \\
\text { experiences in the future } \\
\text { She liked the process and was feeling sorry when it } \\
\text { ended } \\
\text { He forgot the difficulties }\end{array}$ \\
\hline
\end{tabular}

As shown in Table 5, pre-service teachers' opinions about post process were gathered under four categories. These categories are "Perception of Being a Teacher", "Individual Development", "Occupational Development" and "Internship Process".

At the end of the process, pre-service teachers' perceptions of teachership changed in line with student-centered understanding and they liked the teachership profession more. It has been observed that pre-service teachers personally improved themselves in terms of, multi-faceted thinking, problem solving, self-confidence and patience. They also improved themselves professionally in terms of coping with students, preparing plans, and producing activities. It is seen that at the end of the process, pre-service teachers have positive thoughts about the internship process; were satisfied with the process, felt sorry about the completion of the internship and believe that the internship will benefit them in the future. This helped them to forget the difficulties they may have encountered in the process. 
Some quotations from the opinions of the pre-service teachers on this subject are given below:

T1: I am amazed to successfully complete all of the requirements which are internship, pedagogical formation, and university classes. Normally, I have a personality that gets bored of everything immediately. The most important thing is that I learned to be patient during this process.

T2: I realized later that I can teach seven more times. Because every course I participated and every activity I applied taught me new things.

T3: I am sure that this internship process and my guiding teacher will provide benefit me in my future teaching life. I was so used to the internship that it made me sad to finish the internship process and leave.

T4: I now believe that I can do this profession on my own without asking anyone. This internship gave me self-confidence and made me realize my potentials. I realized that the main purpose of teachership is not just give lectures, but teaching something to the students.

Supporting this research, in an other study it was determined that lesson study helps pre-service teachers to do student-centered education, where students' needs and thoughts are taken into account more, as an alternative to subject-based teaching. ${ }^{65}$ In a study, it was determined that the teachers who participated in the lesson study indicated their desire to participate in the process again next year. ${ }^{66}$

\section{Conclusions}

For the pre lesson study process, the study concluded that although the pre-service teachers thought that they were pedagogically insufficient, their self-efficacy beliefs were low, they experienced feelings such as fear, excitement, they were afraid of the tasks they would do, and they believed that the work and operations they would do were unnecessary, yet they provided positive improvement in these matters in the process.

For the lesson study process, the study concluded that pre-service teachers had difficulties in preparing course plans, producing activities and materials during the lesson study process, but they made progress in these issues in the process. It was concluded that pre-service teachers personally improved themselves in terms of versatile thinking, problem solving, self-confidence and

\footnotetext{
65 Ayantaş, "Lesson Study," 119.

66 Rock and Wilson, "Improving Teaching," 90.
} 
patience. It was concluded that during the lesson study process, pre-service teachers had some problems that related to the application of the activities such as adjusting the duration, forming the groups, explaining the instructions, and presentation of the products. But with the revised plans prepared through lesson study, problems were reduced gradually in each class, and these revised plans contributed to the development of the course. It was concluded that in the first weeks, pre-service teachers had more problems in communicating effectively with students, controlling classroom, adjusting their voice tones, implementing the course plans, and ensuring the participation of the whole class in activities and evaluations; however, it was also concluded that they gained experience in time and problems related to these issues have been reduce in recent weeks. During the lesson study, it was concluded that the students were curious and interested in the course, they liked the activities very much, even the ones who never participated the course also participated to it, took responsibility in group works, interacted with each other, produced successful products, and learned effectively in the activities. It was concluded during the lesson study that working with peers contributed to the self-improvements of the pre-service teachers, and that while the guiding teachers contributed to the pre-service teachers, also pre-service teachers contributed to the guiding teachers.

For the post lesson study process the study concluded that pre-service teachers' perceptions of teaching changed in line with student-centered understanding. At the end of the process pre-service teachers had positive thoughts about the teaching practice process, were satisfied with the process, were feeling sad for the process to end, believed that the teaching practice course would be beneficial in the future, and forgot their difficulties.

\section{Recommendations}

In line with the results of the research, the following suggestions have been developed:

- The Ministry of National Education should believe in the importance of lesson study and put some efforts to popularize the model.

- Lesson study method should be shared with teachers through inservice trainings.

- This model should be adapted to the teaching practice courses of universities.

- Lesson study research studies are usually done with mathematics teachers in the literature. These studies should be carried out in different branches. 


\section{Bibliography}

Dağ, Serap Akbaba. “A microteaching Lesson Study Practice to Improve Pre-Service Teachers' Knowledge of Teaching Fractions.” PhD diss., Dumlupınar University, 2014.

Aktürk, Durdu Nur. "Examination of the Mathematics Teachers' Views on the STEM Activities Developed within the Scope of Lesson Study." Master diss., Eskisehir Osmangazi University, 2019.

Aldemir, Ruhşen. "Investigation Development of Prospective Mathematic Teachers' Technological Pedagogical Content Knowledge by Micro Teaching Lesson Study: The Case of Solid Objects.” Master diss., Atatürk University, 2017.

Arastaman, Gökhan. "Examination of Education and Arts and Sciences Faculty Students' Self-Efficacy Beliefs and Their Attitudes Toward Teaching Profession." KEFAD 14, no. 2 (2013): 205-217.

Arseven, Ayla, Burcu Moroğlu, and Ebru Aldı̆̆. "Examination of Prospective Turkish Language Teachers and Turkish Language and Literature Teachers' Self-Efficacy Beliefs.” IJOESS 6, no. 21 (2015): 48-66.

Aslan, Mustafa, and Mecit Sağlam. "Evaluation of Teaching Practice Course According to Opinions of Student Teachers." Hacettepe University Journal of Education 33, no. 1 (2018), 144-162.

Ayantaş, Tolgahan. "Lesson Study Practice in The Development of Professional Teaching Knowledge of Pre-Service Teachers of Social Studies.” Master diss., Ankara University, 2019.

Baki, Müjgan, and Selahattin Arslan. "Examining the Effect of Lesson Study on Prospective Primary Teachers' Knowledge of Lesson Planning." Turkish Journal of Computer and Mathematics Education 6, no. 2 (2015): 209-229.

Baş, Gökhan. "The Effects of Cooperative Learning Method on Students' Achievement, Their Attitude Towards the Lesson and the Maintenance Levels of Their Achieved Knowledge in English Lessons." National Education, no. 184 (2009): 240-256.

Bayram, İlknur, and Fatma B1kmaz. "Exploring the Lesson Study Experience of EFL Instructors at Higher Education: A Pilot Study." Journal of Qualitative Research in Education 6, no. 3 (2018): 313-340.

Birel, Gamze Kurt. "A New Approach in the Context of Mathematics Education Research: Lesson Study." Studies in Educational Research and Development 1, no. 1 (2017): 60-82.

Bjuland, Raymond, and Reidar Mosvold. "Lesson Study in Teacher Education: Learning From a Challenging Case." Teaching and Teacher Education, no. 52 (2015): 83-90.

Boran, Elif, and Kamuran Tarım. "The Opinions of Secondary School Mathematics Teachers about the Lesson Study." Turkish Journal of Computer and Mathematics Education 7, no. 1 (2016): 259-273.

Brinkmann, Svend. Qualitative Interviewing: Understanding Qualitative Research. New York: Oxford University Press, 2013. 
Budak, İbrahim, Ayfer Budak, Işıl Bozkurt, and Bülent Kaygın. "Lesson Study Implementation with Pre-Service Mathematics Teachers." e-Journal of New World Sciences Academy 6, no. 2 (2011): 1606-1617.

Coenders, Fer, and Nellie Verhoef. "Lesson Study: Professional Development (PD) for Beginning and Experienced Teachers." Professional Development in Education 45, no. 2 (2018): 217-230.

Coşkun, Abdullah. "The Application of Lesson Study in Teaching English as a Foreign Language." Inonu University Journal of the Faculty of Education 18, no. 1 (2017): 151-162.

Çelik, Yaşar, and İbrahim Gül. "Evaluation of Teaching Practice Course According to Teacher Candidate's Opinions." Asian Journal of Instruction 6, no. 2 (2018): 81-103.

Dönmez Usta, Necla, and Ebru Turan Güntepe. "Opinion of the Pre-service Teachers on School Experience and Teaching Practice." Journal of International Social Research 9, no. 42 (2016): 1214-1223.

Elkatmış, Metin, Murat Demirbaş, and Nurcan Ertuğrul. "Self-Efficacy Beliefs of Students Who Take the Pedagogic Training Program in the Faculty of Arts and Sciences and Students in the Education Faculty Towards Teaching Profession." Pegem Journal of Education and Instruction 3, no. 3 (2013): 41-50.

Gözel, Emine. "Study of Progress of Class Teachers' Knowledge of ProblemSolving Based Math Teaching by Lesson Study." PhD diss., Pamukkale University, 2016.

Günay, Rafet, Banu Yücel Toy, and Elif Bahadır. "Lesson Study Model in Teacher Education and a Proposal toward Pre-service Teaching Practices in Turkey." Journal of International Social Research 9, no. 42 (2016): 1224-1236.

Güner, Pınar, and Didem Akyüz. "Lesson Study Professional Development Model: Investigating Noticing Skills of Prospective Mathematics Teachers." Elementary Education Online 16, no. 2 (2017): 428-452.

Hamzeh, Fouada. "Lesson Study-Building Communities of Learning Among PreService Science Teachers" Master diss., University of Windsor, 2014.

Iksan, Zanaton $\mathrm{Hj}$, Siti Nor Aishah Mohd Nor, Siti Nordiyana Mahmud, and Effandi Zakaria. "Applying the Principle of "Lesson Study" in Teaching Science." Asian Social Science 10, no. 4 (2014): 108-113.

Kandemir, Esin Meral. "An Application to Improve Teaching Skills of Classroom Teachers: Lesson Study.” PhD diss., Pamukkale University, 2018.

Kaya, Ümit. "Evaluation of Lesson Study Model Based Professional Development Applications of High School Mathematics Teachers" Master diss., Cumhuriyet University, 2018.

Kılıç, Abdurrahman, Mustafa Aydın, Burcu Ökmen, and Şeyma Şahin. Kuramdan Uygulamaya İhtiyaç Belirleme. Ankara: Pegem Yayıncılık, 2019.

Kükey, Hilal. "An Investigation of the Course Planning Process of Pre-Service Primary School Mathematics Teachers on Fifth Grade Fractions Topic Based on Lesson Study Model” PhD diss., İnonu University, 2018. 
Mannathoko, Magdeline. "Does Teaching Practice Effectively Prepare StudentTeachers to Teach Creative and Performing Arts? The Case of Botswana." International Journal of Higher Education 2, no. 2, (2013): 115-121.

McKernan, James. Curriculum Action Research. A Handbook of Methods and Resources for the Reflective Practitioner. London: Kogan Page, 1991.

Meiliasari, Meiliasari. "Lesson Study with Pre-Service Teachers: Investigating the Learning of Pre-Service Teachers in Lesson Study Model of Teaching Practice Course." Fifth International Conference on Science and Mathematics Education CoSMEd, Malaysia, 2013.

Merdekawati, K. "The Implementation of Lesson Study to Improve the Teaching Skills of Chemistry Teacher Candidates." International Conference on Science and Technology, Indonesia, 2018.

Mungure, Daudi Mika. "An Exploration of the Preparation and Organization of Teaching Practice Exercise to Prospective Science and Mathematics Teachers Toward Improving Teaching Profession at Morogoro Teachers' College." Journal of Education and Practice 7, no. 33 (2016): 212-220.

Ngang, Tang Keow, and Lim Chap Sam. "Principal Support in Lesson Study." Procedia-Social and Behavioral Sciences, no. 205 (2005): 134-139.

Özdemir Baki, Gülşah. "Investigating the Development Process of Secondary Mathematics Teachers' Mathematical Pedagogical Content Knowledge: Lesson Study Model." PhD diss., Atatürk University, 2017.

Özen, Deniz. "Development of Geometric Thinking of Elementary School Mathematics Teachers: A Lesson Study." PhD diss., Anadolu University, 2015.

Paker, Turan. "Problems of Student Teachers Regarding the Feedback of University Supervisors and Mentors During Teaching Practice." Pamukkale University Faculty of Education Journal 1, no. 23 (2008): 132-139.

Rock, Tracy C., and Cathy Wilson. "Improving Teaching Through Lesson Study." Teacher Education Quarterly 32 (2005): 77-92.

Rots, Isabel, Antonia Aelterman, Geert Devos, and Peter Vlerick. "Teacher Education and the Choice to Enter the Teaching Profession: A Prospective Study." Teaching and Teacher Education 26, (2010): 1619-1629.

Serbest, Ayşegül. “The Examination of Lesson Study's Impacts with Meta-Synthesis” Master diss., Karadeniz Tecnical University, 2014.

Şan, Selda, and Zafer İbrahimoğlu. "The Impact of Using Student-Centered Activities on Students' Academic Achievement in Social Studies Course and Student's Views." Abant Izzet Baysal University Faculty of Education Journal 17, no. 4 (2017): 2142-2159.

Taylor, C., Wilkie, M., and Baser, J. Doing Action Research: A Guide for School Support Staff. London: Paul Chapman Publishing, 2006.

Tok, Şükran. "The Problems of Teacher Candidate's about Teaching Skills During Teaching Practice." Procedia Social and Behavioral Sciences, no. 2 (2010): 4142-4146. 
Topan, Beyda. "Effects of Student-Centered Methods on Academic Achievement and Attitude towards the Subject: A Meta Analysis Study." Master diss., Kocaeli University, 2013.

Vaughna, Margaret, Seth A. Parsons, Susan Kologi, and Melissa Saul. "Action Research as a Reflective Tool: A Multiple Case Study of Eight Rural Educators' Understandings of Instructional Practice.” Reflective Practice 15, no. 5 (2014): 634-650.

Yeşilyurt, Etem, and Çetin Semerci. "The Problems and Their Solutions of Practice Teachers in Teaching Practice Process.” Akademik Bakış Dergisi, no. 27 (2011): $1-23$.

Yurdakul, Ramazan. "Designing and Evaluation of a Web Site to Facilitate the Implementation Lesson Study Model in In-Service Trainings of Mathematics Teachers." Master diss., Cumhuriyet University, 2019.

Zhou, George, and Judy Xu. "Microteaching Lesson Study: An Approach to Prepare Teacher Candidates to Teach Science Through Inquiry." International Journal of Education in Mathematics, Science and Technology (IJEMST) 5, no. 3 (2017): 235-247.

\section{About the authors}

ABDURRAHMAN KILIÇ (abdurrahmankilic@ duzce.edu.tr) works as a professor at Educational Sciences department of Faculty of Education, Duzce University, Turkey. He works on teacher training, curriculum development, teaching methods and techniques, values education, democracy and human rights, measurement and evaluation, etc.

ŞEYMA ŞAHIN (seyymasahin@gmail.com) received her PhD degree from Duzce University, Institute of Social Sciences, Curriculum and Instruction program. She works on student-centred education, program development, teaching methods and techniques, values education, democracy and human rights. Currently she works as a teacher of Religious Culture and Moral Knowledge Course in a secondary school affiliated with the Ministry of Education. 


\title{
Evaluation of the teaching practice course carried out with the Lesson Study Model
}

\author{
Şeyma Şahin and Abdurrahman Kılıç
}

doi: http://dx.doi.org/10.18543/tjhe-8(1)-2020pp99-127

\section{Copyright}

Copyright for this article is retained by the Publisher. It is an Open Access material that is free for full online access, download, storage, distribution, and or reuse in any medium only for noncommercial purposes and in compliance with any applicable copyright legislation, without prior permission from the Publisher or the author(s). In any case, proper acknowledgement of the original publication source must be made and any changes to the original work must be indicated clearly and in a manner that does not suggest the author's and or Publisher's endorsement whatsoever. Any other use of its content in any medium or format, now known or developed in the future, requires prior written permission of the copyright holder. 